\title{
Mother's knowledge, attitude and practice determination of fever Management of children at Home Rural areas of Lahore
}

\author{
Shahida Parveen, \\ Lahore School of Nursing \\ The University of Lahore \\ Lahore, Pakistan \\ Muhammad Afzal, associate professor \\ Lahore School of Nursing \\ The University of Lahore \\ Lahore, Pakistan \\ Muhammad Hussain, Assistant Professor \\ Lahore School of Nursing \\ The University of Lahore \\ Lahore, Pakistan \\ Prof. Dr. Syed Amir Gilani \\ Lahore School of Nursing \\ The University of Lahore \\ Lahore, Pakistan
}

\begin{abstract}
Fever is common problem in children. Most these episodes are managed at home unless consultation from a consultant. Mothers' response to fever will depend on their perception of its cause and Knowledge about how it can be manage. The aim of this study is evaluate mothers' perceptions of fever and its Management at home.

Methods: This was a community based descriptive study. It involved the distribution of questionnaires of 19 items on fever and related questions to 110 mothers. Data was analyzed using descriptive statistics. Results: The age of 110 mothers who were participated is 19 years to 45 years. Mothers check temperature not from proper place. And gave no proper dose of accurate medicine. Conclusion: Mothers of rural areas of Lahore have good Knowledge about fever however there is need to educate them on the use of thermometer and proper use of drugs.
\end{abstract}

Keywords: Mother s perception, fever, and children

DOI: $10.7176 / \mathrm{JHMN} / 67-12$

Publication date:October $31^{\text {st }} 2019$

\section{INTRODUCTION}

Elevation in body temperature is a fever. Oral measurement of 98.6 Fahrenheit (37 Celsius) or the normal rectal temperature of $99 \mathrm{~F}(37.2 \mathrm{C})$ is considered higher. However, these are averages, and one's normal body temperature may actually be $1 \mathrm{~F}(0.6 \mathrm{C})$ or more above or below the average of $98.6 \mathrm{~F}$. Body temperature can also differ up to 1 F (0.6 C) (Athamneh, El-Mughrabi, Athamneh, Essien, \& Abughosh, 2014)

Fever management is a technique in which mothers do some practices for fever diminish. There is no need for fever management if it does not cause uneasiness. It is not necessary to stimulate an adult or child to manage a fever unless doctor advised to do so (Athamneh et al., 2014).

A child who is suffering from fever should be kept in comfortable and not overdressed. Overclothing also can cause fever. Tepid water $(85 \mathrm{~F}[30 \mathrm{C}])$ baths or sponge baths are a home remedy it also help in fever management. Never give bath with cold water to a feverish person. This is a very common mistake. Never sponge a child with alcohol; inhaled fumes of alcohol can causing many problems

Home remedies for fever controlling is include keep on hydrated. Drink sufficiently water and fluids, and avoid alcohol or caffeinated drinks, which can help to dehydration (Logo, F. W. (2011). Fever).

In childhood fever is very common problem and is one of the major cause that parents bring their children for medical care. In general practice of any pediatrician fever is a major complain which is about $1 / 3^{\text {rd }}$ of all 
complains.( Lagerlov P, Helseth S, Holager T. Childhood illnesses and the use of paracetamol (acetaminophen):): Fever is increase body temperature. Fever is the body's natural response to fight with infections like cough and cold. Feel warm than routine to the touch on their forehead back or belly. Have red galls. Normal temperature in babies and children is about $36.4 \mathrm{C}$, but this can differ slightly from child to child. In many studies range of fever is $37.5 \mathrm{C}$ to $37.9 \mathrm{C}$ and high fever is ranging from $38.4 \mathrm{C}$ to $39.1 \mathrm{C}$ and in dangerous level is $39.3 \mathrm{C}$ to $39.9 \mathrm{C}$.

Infect fever itself is not a disease but it is the process by which body fights infection, (Athamneh, El-Mughrabi, Athamneh, Essien, \& Abughosh, 2014). Fever after immunization; current concepts and proved future scientific understanding. (Clin fect, 2004). This increases the neutrophils production and increase T. lymphocytes production which improves the defense mechanism.

Fever is most common problem in children. Most of them are treated at home by mother's perception without any consultation or advice by the physician who find the cause of fever and managed

In rural areas of Lahore mothers mostly check fever of their children with their hands not use any thermometer and gave anti pyrexia medicine without any prescription by any physician. In mostly cases mothers' gives aggressive antipyretic treatment in incorrect doses. 51\% mothers gave 6 hourly ibuprofen and $14 \%$ to $27 \%$ gave more frequently before 4 hours. $33 \%$ to $50 \%$ gave ibuprofen at less than 6 hours

Self-medication has customarily been labeled as "the taking of medicines, herbs or home remedies on one's own personal initiative, or on the advice of other person, without consulting a health physician. (Patil et al., 2014)

\section{AIMS OF THE STUDY}

The aim of this study is improves the knowledge and believes of mothers regarding childhood fever and its management at home. Prevent children from complication of fever and unnecessary medications.

\section{SIGNIFICANCE OF THE STUDY}

Pakistan among 10 countries with uppermost level of child death.60 present of the world's 5.9 million children who died within the first year of life.

Many child died with pneumonia, fever, meningitis and other reason due to unawareness and lack of knowledge about fever. Some time they don't feel any emergency and child become serious.

In many homes parents gave excessive medicine for very low grade fever. And some time times mothers give previous prescribed medicine without advice by physician.

After this study parents will be able to manage fever of children in home accurately. Mother's practice regarding become healthy, happy and stronger then country defiantly will become stronger.

\section{LITERATURE REVIEW}

Fever is very common in childhood. Parents have been exposed to have unlikely fears, resulting in incorrect management of fever in their children (AL Eissa al et, 2000).

According previous studies One hundred and thirteen $(74.8 \%)$ participants defined fever as high temperature of the body, while One hundred and twenty one (80.2\%) mothers knew that a child had fever when his/her body was hot, while 7(4.6\%) believed fever is present when there is loss of appetite .The commonest identified that lack of appetite is also a symptoms of fever in 108(71.5\%), while the least associated symptom was yellowness of the eyes 5(3.3\%) shows the others.(Alex-Hart \& Frank-Briggs, 2011)

Purpose of my study is to assess mother's knowledge attitude and practice for controlling of fever in children under 10 years of age at home. It is proved by many studies that less than $20 \%$ parents use digital or electronic thermometer, it is the best way to check temperature at home

More than $68 \%$ used their hands to check fever. it is not recommended because measuring by hands has been shown to be incorrect result falsely identifying that child has fever. (Athamneh et al., 2014) 
In this study I will know that how parents check fever and how use thermometer I will inform them about right way to check fever and how use the thermometer. Lines for world

The guild lines from world Health Organization (WHO) recommended treatment when temperature is above 38.5 degree centigrade. (World Health Organization. Hand book IMCI; integrated management of childhood illness.)

In my study I will teach the mothers of rural areas of Lahore low temperature and high temperature and I will told them when they need anti pyrexia drug mostly people gave anti pyrexia and anti-biotic drugs without any physician's prescription. I will told them about hazers of excessive use medicine. $44 \%$ mothers keep age of child in mind when they manage fever of their child at home and 38\% mothers keep fever in mind while $10 \%$ only considered weight as a very important factor to take into consideration before choosing the dose of medicine for fever control.

\section{SETTING}

A descriptive study was conducted in rural areas of Lahore children under 10 years of age.

\section{Population:}

I was collected data from rural reas of Lahore 110 homes

\section{SAMPLING}

Convenient sampling was used for the data collection

\section{RESEARCH INSTRUMENT}

5 point closed end Likert scale questionnaire adopted from the literature of (Uppal D et al., December 2014) was used as a research tool. Questionnaire consist of 2 parts first consists on demographic data of participant and second is Likert scale questionnaire which is further divided into 4 subparts focusing on part 1 knowledge of self-medication part 2 attitude towards self-medication, part 3 practice of self-medication, part 4 reasons for the use of self-medication, Questionnaire comprises of 21 quantitative questions.

\section{DATA GATHERING PROCEDURE}

Ethical clearance to conduct the study was obtained from Institution Review Board Committee the University of Lahore. Permission from community stakeholder was taken to collect health and demographic data in the community. The rules and regulation of community were followed. No personal identity of participants were revealed. No participant was forced to take part in research work. All the confidential data treated confidentially.

\section{METHODS USED TO ANALYZE DATA}

Data analysis was done using SPSS version 21.

\section{STUDY TIMELINE}

The study was conducted from September 2017 to January 2018 in the rural area of Lahore and the duration of this study is three months.

\section{ETHICAL CONSIDERATION}

- Veracity. Information was given to participants about the purpose of the study.

- Confidentiality. To keep the confidentiality intact, coding was made so that personal info of participants may not reveal.

- Non maleficence. No participant was forced to take part in study or to fill questionnaire without own willingness. No sensitive information was obtained.

- Autonomy. Informed consent was attached with each questionnaire. 
- Justice. No biasness was involved in conducting study and analyzing data. Fair results were concluded.

Research Question - Is the health of children effected by illiteracy of mothers?

\section{RESULTS}

The study population is Husain Abad community and target population is mothers having children. 110 participants were response against questionnaire in which includes 15 to above 45 years old.

Data collected from the rural residents of the Husain Abad community, Lahore to determine the knowledge, attitude and practices of mother regarding children fever management, and they show $100 \%$ response to the current study. The data analysis consists of two parts. Demographic is the first part of data analysis which gives details about demographic variables. Second part is descriptive analysis which provides us recurrence and rate of respondent regarding 21 item of questionnaire.

$\underline{\text { Section } 1}$

Table 1 depicts that participants of the study were $n=110$, male 0 and female were 110 .

19 to above 45 year old participants were responded as, (83) $72.8 \%$ were $15-30$ year old, $36.6 \%$, (24) $21.1 \%$ were 31-45 year old and above 45 year old participants responded as (3) $2.6 \%$. The statistical report shows in table 1 that the participants between the ages of 15-30 year old percentage is high between selected age group and above 45 year old is low. Mostly participants' education was, 66 (57.9\%) Primary, 29 (25.4\%) matriculation, and 15 $(13.2 \%)$ not qualified/illiterate.

Demographic data involve gender, age, qualification, is further individually described as bellow.

Table 1 Demographic Characteristics

$\begin{array}{llcr}\text { Variable } & \text { category } & \text { F } & \% \\ \text { Age } & 15-30 & 83 & 72.8 \\ & 31-45 & 24 & 21.1 \\ \text { Education } & \text { Above } 45 & 3 & 2.6 \\ & \text { illiterate } & 15 & 13.2 \\ & \text { Primary } & 66 & 57.9 \\ & \text { Matriculation } & 29 & 25.4\end{array}$

Section 2

Table 2 demonstrate the knowledge of mothers towards fever management..

In reaction of (1-7) items questionnaire which were used to determine the knowledge of participants towards the management of fever and majority of the respondent's express positive knowledge by circle their response in the favor of fever management. Majority of them shows positive knowledge but, little percentage of participants show poor knowledge. Complete details presents in table 2 .

The percentage of mothers who have knowledge about normal temperature of the children is $66.7 \%$ and frequency is 767 present of mothers have knowledge about fever and frequency is 8 .

TABLE 2 KNOWLEGDE REGARDING FERVER MANAGEMENT

STATEMENT

In home,

With the

$\mathrm{F} \%$

often check

thermometer

temperature

$\begin{array}{lcc}\begin{array}{l}\text { Paper } \\ \text { thermometer }\end{array} & 4 & 3.5 \\ \text { Don't know } & 18 & 15.8 \\ \text { By hand } & 32 & 28.1 \\ \text { The rectum } & 64 & 48.1\end{array}$

Best sites for

The rectum

temperature?

$\begin{array}{lll}\text { The mouth } & 49 & 36.8 \\ \text { The axilla } & 19 & 14.3\end{array}$


what is the normal

temperature

the

temperature

you consider

of fever?

$38 \mathrm{C}$

$37 \mathrm{C}$

$41 \mathrm{C}$

$38 \mathrm{C}$

How much

child before

going to the

doctor?

$39 \mathrm{C}$

$40 \mathrm{C}$

$41 \mathrm{C}$ fever of your

After 15 mints
From 15 to half

an hour

When your

child suffering

from fever you

check his

temperature

every :

From half an on

hour

From one to two

hours

Seizure

Brain damage

Brain damage

Dehydration
$12 \quad 10.5$

$\begin{array}{ll}76 & 66.7\end{array}$

$13 \quad 11.4$

$9 \quad 7.9$

$8 \quad 7.0$

$50 \quad 43.9$

$40 \quad 35.1$

$\begin{array}{ll}12 & 10.5\end{array}$

$1 \quad 0.9$

$29 \quad 25.4$

$65 \quad 57$

$15 \quad 13$

$6 \quad 5.3$

10.5

12

26.3

30

54

62

$34 \quad 29.6$

$28 \quad 24.6$

$12 \quad 10.5$

$36 \quad 31.6$

Section 3

Table 3 demonstrate the practices of mothers towards fever management..

In reaction of (1-6) items questionnaire which were used to determine the practices of participants towards the management of fever and majority of the respondent's express good practices by circle their response in the favor of fever management. Majority of them shows good response but, little percentage of participants show unsatisfactory. Complete details presents in table 3.

In my study $61 \%$ of mothers gave medicine of fever management to the children's according to leaflet of the medicine and 7 of frequency of this. 
TABLE 3 PRACTICE REGARDIG FEVER MANAGEMENT

\begin{tabular}{|c|c|c|c|}
\hline \multirow{4}{*}{$\begin{array}{l}\text { Which drugs do } \\
\text { you give to } \\
\text { your child who } \\
\text { is suffering } \\
\text { from fever? }\end{array}$} & Panadol & 29 & 25.4 \\
\hline & Brufine & 58 & 50.9 \\
\hline & Aspirin & 5 & 4.4 \\
\hline & Antibiotics & 18 & 15.8 \\
\hline \multirow{4}{*}{$\begin{array}{l}\text { do you chose } \\
\text { the right fever } \\
\text { let down } \\
\text { Drugs }\end{array}$} & $\begin{array}{l}\text { previously } \\
\text { advised } \\
\text { meds }\end{array}$ & 53 & 46.4 \\
\hline & $\begin{array}{l}\text { Pharmacy } \\
\text { person }\end{array}$ & 50 & 43.9 \\
\hline & $\begin{array}{l}\text { information } \\
\text { through } \\
\text { media }\end{array}$ & 4 & 3.5 \\
\hline & $\begin{array}{l}\text { Decide } \\
\text { myself. }\end{array}$ & 3 & 2.6 \\
\hline \multirow{5}{*}{$\begin{array}{l}\text { Dose of fever } \\
\text { lowering drugs } \\
\text { you give for } \\
\text { treat fever? }\end{array}$} & pediatrician & 31 & 27.2 \\
\hline & $\begin{array}{l}\text { Reading the } \\
\text { leaflet }\end{array}$ & 7 & 61 \\
\hline & $\begin{array}{l}\text { C0nsulting } \\
\text { pharmacist }\end{array}$ & & \\
\hline & I call me & 28 & 24.6 \\
\hline & & 44 & 38 \\
\hline \multirow{3}{*}{$\begin{array}{l}Z \text { Fever not } \\
\text { settled you gave } \\
\text { additional } \\
\text { Medicine. }\end{array}$} & Yes & 25 & 21.9 \\
\hline & No & 47 & 41.9 \\
\hline & don't know & 38 & 33.3 \\
\hline \multirow{5}{*}{$\begin{array}{l}\text { in addition to } \\
\text { drug which } \\
\text { other home } \\
\text { remedies are } \\
\text { used? }\end{array}$} & Cold & 42 & 36.8 \\
\hline & spong & 12 & 10.5 \\
\hline & $\begin{array}{l}\text { Icepack } \\
\text { tepid }\end{array}$ & 46 & 40.4 \\
\hline & $\begin{array}{l}\text { Taped } \\
\text { sponging }\end{array}$ & 10 & 8.8 \\
\hline & only drugs & & \\
\hline \multirow{4}{*}{$\begin{array}{l}\text { : when give an } \\
\text { medicine to } \\
\text { your child you } \\
\text { consider: }\end{array}$} & Age & 28 & 24.6 \\
\hline & Sex & 11 & 9.6 \\
\hline & Weight & 31 & 27.2 \\
\hline & $\begin{array}{l}\text { Severity of } \\
\text { fever }\end{array}$ & 40 & 35.1 \\
\hline
\end{tabular}

Section 4

Table 4 demonstrate the attitude of mothers towards fever management.. 
In reaction of (1-2) items questionnaire which were used to determine the attitude of participants towards the management of fever and majority of the respondent's express positive attitude by circle their response in the favor of fever management. Majority of them shows positive attitude but, little percentage of participants show negative attitude. Complete details presents in table 4.

The outcomes exhibit $110(71.00 \%)$ respondents indicate favorable attitude towards children education responses against 21 items questionnaires. 43(29\%) responded shows (disagree and strongly disagree) unfavorable attitude

\section{TABLE 4 ATTITUDE TOWARDS FEVER MANAGEMENT}

\begin{tabular}{|c|c|c|c|}
\hline \multirow{4}{*}{$\begin{array}{l}\text { You give an antibiotic drug } \\
\text { if your child: }\end{array}$} & He has a fever & 58 & 50.9 \\
\hline & You suspet an infection & 30 & 26.3 \\
\hline & Found information on net & 16 & 14.0 \\
\hline & & 6 & 5.3 \\
\hline \multirow{4}{*}{$\begin{array}{l}\text { When you go pharmacy to } \\
\text { buy antibiotic drug, you } \\
\text { frequently: }\end{array}$} & Have prescription & 69 & 60.5 \\
\hline & Deeside by yourself & & \\
\hline & according information & 35 & 30.7 \\
\hline & Don't know & 5 & 4.4 \\
\hline
\end{tabular}

\section{DISCUSSION}

In my study we explored knowledge, beliefs and attitudes of mothers of rural areas of Lahore in managing the fever of children at home.

In this study mothers should be encouraged to check temperature from the axilla not check from mouth of the children's. Use thermometer for check temperature of the child at home which is the most accurate way of fever check. More than $6828 \%$ used their hands which is not recommended because check fever by hand has been shown incorrect results by falsely identifying that child is suffering from fever and there is a risk of metal poisonousness with mercury thermometer use.

Studies found that physical procedures used to manage fever such as bathing, cold sponging, application of ice bags, and rubbing the body with these methods may paradoxically increase fever, have dangerous side effect such as shaking, shivering, severe hypoglycemia, or lead to coma. Consequently, physical methods to fever management are not recommended excepting cases of hyperthermia. However, in my study I found mothers in rural areas of Lahore gave Brufine and Panadol for fever without consult to doctor, when asked to the mothers about its reason most reported that it is more useful. On the other hand, more mothers gave medicine to their children after asking pharmacist and someone gave by self. And gave antibiotics no properly.

\section{LIMITATIONS}

Non-probability sampling technique was applied in the study. The study was conducted in rural area of Lahore.

\section{CONCLUSION}

Our results indicate that mothers of rural areas of Lahore use incorrect method for check fever of the children and use improper medicine to reduce fever of child in home.

As the data suggest that a high ratio of Mothers use the oral route for check temperature and medication Administration, Educational programs may be needed to ensure the Process of taking temperature by exile and arrange educational programs about medications use and ensure them to do not use antibiotics without advice by physician.

\section{ACKNOWLEDGEMENT}

Author's heart is filled with the feeling of gratitude toward God Almighty and then all the faculty of Lahore School of Nursing especially Mr. Muhammad Afzal, Mr. Muhammad Husain and Miss Hajira Serwer who 
guided me on every step of this work. I also feel grateful to my family and friends especially my mother for always remaining encouraging and supporting in every aspect of life.

\section{REFERENCES}

AleX-Hart, B. A., \& Frank-BriggS, A. I. (2011). Mothers' PERCEPTION OF FEVER MANAGEMENT IN CHILDREN. NigERIAN HEALTH JOURNAL, 11(2), 69-72

Oshikoya, K., \& Senbanjo, I. (2008). Fever in children: Mothers' perceptions and their home management. Iranian Journal of Pediatrics, 18(3), 229-236.

Chiappini, E., Parretti, A., Becherucci, P., Pierattelli, M., Bonsignori, F., Galli, L., \& de Martino, M. (2012). Parental and medical knowledge and management of fever in Italian pre-school children. BMC pediatrics, 12(1), 97.

Athamneh, L., El-Mughrabi, M., Athamneh, M., Essien, E. J., \& Abughosh, S. (2014). Parents' knowledge, attitude and beliefs of childhood fever management in Jordan: a cross-sectional study.

Betz Journal of Applied Research on Children: Informing Policy for Children at Risk, 5(1),

M. G., \& Grunfeld, A. F. (2006). 'Fever phobia'in the emergency department: a survey of children's caregivers European Journal of Emergency Medicine, 13(3), 129-133.

Betz, M. G., \& Grunfeld, A. F. (2006). 'Fever phobia'in the emergency department: a survey of children's caregivers. European Journal of Emergency Medicine, 13(3), 129-133. 